\title{
William Blake's Visions and the Unio Artistica ${ }^{1}$
}

\author{
By BO LINDBERG
}

Early writers on William Blake were very much attracted by his visions. They presented the sensational stuff with remarkable dramatic skill, using it as evidence of Blake's being either eccentric, insane or divine. ${ }^{2}$

Modern scholars, on the other hand, refuse to take the visions seriously, explaining away Blake's descriptions of them as "poetic language" and rejecting the visionary heads as a hoax, with which Blake amused himself at the expense of credulous friends. ${ }^{3}$

1 The present article forms part of a work in progress, dealing with William Blake's illustrations for the Book of Job.

2 Cf. "Nativity of Mr. Blake The Mystical Artist", Urania, or, The Astrologer's Chronicle, No. I, London, Dec. 20th, I825, p. 7 r. John Varley, $A$ Treatise of Zodiacal Physiognomy, London 1828 , gives a detailed account of the apparition of the Ghost of a Flea, cf. below, p. I44, note $\mathrm{x}$. In the Revue Britannique, Juillet I833, appeared an interview with Blake "le Voyant" in the Bedlam Madhouse "Statistique. Hôpital des fous à Londres". Blake was never in Bedlam, and the interview is altogether false. It was quoted as fact by A. Brierre de Boismont, Des Hallucinations, Paris I 845 (Engl. transl. London 1859, pp. 83-85), and by John Timbs, English Eccentrics and Eccentricities, London 1866, I, pp. 67-69, 2nd ed., I875, p. 346. The article in the Revue Britannique is compiled and distorted from a sensational but correct notice, "Bits of Biography, Blake, the Vision Seer, and Martin, the York Minster Incendiary", The Monthly Magazine, March 1833. Biographical notes on Blake occur in John T. Smith, Nollekens and his Times, London, 1828 , and in the diary of Henry Crabb Robinson (cf. below, p. I42, note 2). Allan Cunningham, "William Blake", The Lives of the most Eminent British Painters, London 1830, II (I quote the 5th ed. (by William Sharp), Great English Painters, London n.d., pp. 288 f., 297 ff.) gives many a detailed eye-witness account. The first signs of a mild scepticism as to the accuracy of Blake's visionary language are found in Gilchrist's standard biography. Cunningham, ed.cit. p. 30o, says that, "These stories are scarcely credible, yet there can be no doubt of their accuracy", but David Erdman, Blake. Prophet Against Empire, 1954, dismisses all this as the "distorting journalism of Alan [sic!] Cunningham and Jane Porter". (p. 455). Cf. Miss Jane Porter, The Scottish Chiefs, II, London, I84I, pp. $466 \mathrm{ff}$.

3 Those who try to explain away Blake's visionary experience as a kind of poetic language, are best put right by Blake's own words, defending Plato and Milton against the same suspicion, in a marginal annotation to Reynolds' Discourses: "The Ancients did not mean to Impose when they affirm'd their belief in Vision \& Revela- 
Few, however, have entered into the problems seriously; ${ }^{1}$ sceptic scholars reject Blake's visions, not because they know that Blake had none, but because they think that visions cannot be seen at all, except by lunatics. ${ }^{2}$ Reports about visions should be treated like reports about ghosts, this seems to be a general belief among 20 th century scholars.

The visions, as described in Blake's writings and drawings, in Crabb Robinson's diary, or in Cunningham's and Gilchrist's biographies are detailed, intelligible and reasonable. ${ }^{3}$ They would be readily believed by anyone, if they were not descriptions of visions.

tion. Plato was in Earnest: Milton was in Earnest. They believ'd that God did Visit Man Really \& Truly \& not as Reynolds pretends.", The Complete Writings of William Blake, ed. Geoffrey Keynes, London I 966, p. 473. (All subsequent references are to this edition, if not otherwise stated.) Among the advocates of the poetic language theory are Gilchrist, who was followed by S. Foster Damon, "Spirits and Their Dictation", William Blake, his Philosophy and Symbols, London etc. I924, pp. I96 ff. (2nd ed. 1947); and Mona Wilson, The Life of William Blake, London 1927, 2nd revised ed., r 948, pp. $270 \mathrm{ff}$. The distinguished Blake scholar, Sir Geoffrey Keynes, thinks that the accounts as given by Varley are exaggerated, cf. A Bibliography of William Blake, New York I92I, No. 249. The hoax theory is formulated by William Gaunt, Arrows of Desire, London i956, pp. I26 f., who follows the anti-mystic Blake interpretations of Mark Schorer (William Blake, The Politics of Vision, New York, i 946). It should be mentioned that Damon later altered his opinion, in his $A$ Blake Dictionary, Providence, Rhode Island I965, cf. below, note 2. Even so careful a scholar as G. E. Bentley uses the word 'joke' when telling about the visionary heads, G. E. Bentley \& Martin K. Nurmi, A Blake Bibliography, Minneapolis 1964 , p. 9.

${ }^{1}$ Helen C. White, The Mysticism of William Blake, New York I927, reissued in $\mathrm{r}_{964}$, gives a systematic investigation of Blake's mysticism (and concludes that he was not a mystic), but ignores his visions, and does not enter into the problems of his pictorial art, "a fascinating field in itself, but, except for incidental references, excluded by definition from a study of Blake's writings" (2nd ed., p. 207). Much confusion as to the questions of Blake's mysticism and his visions are due to the general dislike to use his pictorial art as a source of information. The only comprehensive, sound investigation of Blake's pictorial imagination yet to have appeared is Anthony Blunt's The Art of William Blake, New York i 959, but he, unfortunately, has little to say about Blake's visions.

2 S. Foster Damon, who formerly explained Blake's visions as "poetic language", has recently described them as a kind of wake-up dreams, and compared them to the "color visions of peyote" (A Blake Dictionary, p. 436), thus introducing a modern psychiatric explanation, not very different from the old madman-hypothesis of Henry Crabb Robinson and Brierre de Boismont; the word "peyote" clearly indicates something abnormal.

${ }^{3}$ Henry Crabb Robinson, On Books and their Writers (ed. Edith Morley), London 1938, pp. 40, 4I, 355, 498, 752. Alexander Gilchrist, The Life of William Blake 
They could, of course, be accepted as hallucinations, provided that Blake was insane. But all modern writers deny that he was. ${ }^{1}$ All friends of Blake, almost all of his acquaintances, and almost all early writers are of the same opinion. Those who are not, cannot find anything insane in Blake except the visions. ${ }^{2}$

The problem is: how can these visions be reconciled with a sane mind? In old times the answer would have been easy: because the visionary is a prophet, because he is a saint. But modern man is not so easily satisfied. He would sooner believe the most far-fetched pseudo-rationalist explanation, than accept as a simple fact that man can see God with his own eyes. Of course, we could say that Blake was a mystic. But what does that mean? We could also say, that Blake was not a mystic, only an eidetic. The problem, however, is not solved by that simple etiquette.

Blake's friends, eye witnesses when Blake was visited from above, might help us, and so might Blake's drawings and writings.

Few of William Blake's creations have achieved such fame as his prophile portrait of the ghost of a flea. John Varley writes:

"This spirit visited his [Blake's] imagination in such a figure as he never anticipated in an insect. As I was anxious to make the most correct investigation in my power, of the truth of these visions, on hearing of his spiritual apparition of a Flea, I asked him if he could draw for me the resemblance of what he saw: he instantly said, 'I see him now before me'. I therefore gave him paper and a pencil, with which he drew the portrait, of which a facsimile is given in this number. I felt convinced by his mode of proceeding that he had a real image before him, for he left off, and began on another part of the paper to make a separate drawing of the mouth of the Flea, which the spirit having opened, he was prevented from proceeding with the first sketch, till he had closed it. During the time occupied in completing the drawing, the Flea told him that all fleas were inhabited by the souls of such men as were by nature blood-thirsty to excess, and were therefore providentially confined to the

London I863; 4th ed., by Ruthwen Todd, I942, Chap. XXVIII, "John Varley and the Visionary Heads", pp. $262 \mathrm{ff}$. and Chap. XXXV, "Mad or Not Mad?", pp. 3 I 7 ff. (all subsequent references are to Todd's edition). Cf. also above, p. I4I, note 2.

1 The only modern influential writer who has called Blake mad is G. K. Chesterton. He thinks Blake was insane because he used the same figure in different paintings and the same phrase in different poems. The point cannot be taken seriously, and is explained only by Chesterton's endeavour to be in all matters of another opinion than the common one. Chesterton, William Blake, London and New York r.9ro.

${ }_{2}$ The only one among all who actually knew Blake, to think that he was insane, was Henry Crabb Robinson, and he thought so because otherwise he could not have understood how Blake could have had any visions. Cf. Gilchrist, ed. cit., p. 333. 
size and form of insects; otherwise, were he himself, for instance, the size of a horse, he would depopulate a great portion of the country." 1

Among Blake's almost 40 visionary portraits one more deserves special attention, the full face portrait of the spirit of Voltaire. ${ }^{2} \mathrm{He}$ is represented as a young man, with broader forehead, larger eyes, wider nostrils and a more serene and determined look than we are used to from other portraits. Still the likeness is good. Blake shows us Voltaire spiritualized. Blake had, writes Henry Crabb Robinson, much visionary intercourse with Voltaire :

" 'I have had much intercourse with Voltaire, and he said to me: "I blasphemed the Son of Man, and it shall be forgiven me; but they [the enemies of Voltaire] blasphemed the Holy Ghost in me, and it shall not be forgiven them."' I asked him in what language Voltaire spoke. He gave an ingenious answer: 'To my sensations it was English - it was like the touch of a musical key. He touched it probably French, but to my ear it became English.' "';

Among the witnesses Blake himself may be heard. In pl. 40 of Milton he gives a delineation of one of his visions. The artist is shown standing in his garden outside his house, which is carefully inscribed "Blake's Cottage Felpham". ${ }^{4} \mathrm{He}$ is looking upwards, where, in the sky, a female figure appears. The vision is described in the text; and we are told that the figure is Ololon, a personage known to us only from Blake's writings. She is, consequently, an inhabitant of Blake's brain. A moment ago she was still inside his head -now she has stepped out, to appear before her creator's eyes.

Milton was written at Felpham between I800 and I803, and engraved

1 The story is told by John Varley in A Treatise of Zodiacal Physiognomy, pp. $54 \mathrm{f}$., where a facsimile of Blake's drawing of the Ghost of a Flea appeared, in an engraving by John Linnell. The original drawing is in the Tate Gallery, no. $5 \mathrm{I} 84$. Cf. Martin Butlin, The Works of William Blake in the Tate Gallery, 1957, no. 46 recto, repr. pl. 26. Blake also made a full length tempera painting of the ghost (the Tate, no. 5889), Butlin, op. cit. no. 47, repr. pl. 25. This, also, was engraved by Linnell, but never published. Linnell made a coloured copy of the head of the flea; cf. Gilchrist, ed. cit., p. 266.

2 Owned by dr. John Lipscomb. Repr. Keynes, Pencil Drazings by William Blake, II, London 1956, no. 33 .

${ }^{3}$ Robinson, ed. cit., p. 333 .

4 For a reproduction, see the facsimile edition by the William Blake Trust, I967. Most of Blake's books in illuminated printing have appeared in the series. 
from I804 on, after Blake's return to London. In plate $4^{\circ}$ Blake simply depicts one of the Felpham visions, which inspired him to write Milton.

Are these visions a hoax? Can they be explained away with the words of Gaunt, as a blakean joke with the credulous astrologer John Varley? ${ }^{\text {I }}$ The present writer cannot believe that.

If Blake fooled Varley, he fooled all his friends, among them many sensible men like John Linnell and Henry Crabb Robinson. ${ }^{2}$ If he fooled Varley he fooled his wife-whom he taught to see visions-and he fooled posterity. ${ }^{3} \mathrm{He}$ started fooling his father, when, as a boy, he saw angels sitting in the trees at Peckham Rye, and continued with such things all his life, till he finally died singing songs, of which he stubbornly said, "They are not mine."' Who would take such lifelong pains, just to make jokes? Blake certainly heard what he wrote, and saw what he drew. But, we may ask, where did he see it? None but Varley was naive enough to try to see what Blake saw, and stare in the same direction as he. ${ }^{5}$ Blake himself denied that his visions were seen by the corporeal eye. When a lady asked him where he saw them, Blake is reported to have knocked his head and said, "Here, madam". ${ }^{6}$

Blake made a careful distinction between the hallucinations of a lunatic and the visions of a sane mind, when he said that a ghost is a thing seen by the gross bodily eye, a vision by the mental. ${ }^{7}$ "Did you ever see a ghost?", asked a friend. "Never but once", was the reply. Gilchrist writes:

\footnotetext{
"Standing one evening at his garden door in Lambeth, and chancing to look up, he saw a horrible grim figure, 'scaly, speckled, very awful', stalking downstairs towards him. More frightened than ever before or after, he took to his heels, and ran out of the house."'s
}

${ }^{1}$ William Gaunt, Arrows of Desire, pp. $126 \mathrm{f}$.

2 Robinson, ed. cit., p. 325 " ... and when he said 'my visions' it was in the ordinary unemphatic tone ... In the same tone he said repeatedly: "The Spirit told me."

'Blake's wife believed in Blake's visions, and even learned to see them. Cf. Gilchrist, ed. cit., p. 3 I5. See also below, p. 16r, note 3 .

4 Gilchrist, ed. cit., pp. 6, 352 .

5 "Varley, meanwhile, straining wistful eyes into vacancy and seeing nothing, though he tried hard." Gilchrist, ed. cit., p. 263.

6 Gilchrist, ed. cit., p. 317.

7 Ibid., p. 107.

8 Ibid., p. 107. 
This sounds very much like the catholic distinction between corporeal and imaginative visions, or, to use the terminology of modern psychology, between hallucinations and eidetic phenomena. ${ }^{1}$

Hallucinations are really seen by the "gross bodily eye"; they are always confused with reality, and normally make those who see them frightened and upset. They are seen by lunatics, by people who have consumed drugs or spirits, by people who are half-asleep, ill, extremely tired and over-stressed, and by victims of hypnosis and suggestion, that is, they are the product of abnormal mental processes. ${ }^{2}$

Eidetic phenomena, on the other hand, are anything but abnormal. They occur in perfectly lucid mental states. They are of a character very different from "natural things", as Blake would have said. They often appear colourless, like black-and-white photographs, they can look like pictures, are often flat, are sometimes more vividly coloured or more sharp in outline, more rich in detail, or appear in a stronger, more radiant light than ordinary things. ${ }^{3}$

These visions seem to be produced by a spontaneous activity in the brain. The eye is not always necessary for their appearance; at least some of them can be seen with the eyes shut, as dreams can. They are often, but not always, subject to the will of the visionary. ${ }^{4}$ The traditional practice of the

${ }^{1}$ Cf. Tor Andrae, Mystikens psykologi, Uppsala I926, p. 216.

${ }^{2}$ Cf. below, note 3 , and p. I47, note $\mathrm{I}$.

a Cf. Karl Schmëing, Geschichte des Zweiten Gesichts, Bremer-Horn 1950, p. I8, and Andrae, Mystikens psykologi, pp. 216 f., $593 \mathrm{ff}$. Blake said about the visionary figures that they were "grey but luminous, and superior to the common height of men". (Cunningham, ed. cit., p. 288). Moreover he said: "A Spirit and a Vision are not, as the modern philosophy supposes, a cloudy vapour, or a nothing: they are organized and minutely articulated beyond all that the mortal and perishing nature can produce. He who does not imagine in stronger and better lineaments, and in stronger and better light than his perishing and mortal eye can see, does not imagine at all. The painter of this work (The Bard) asserts that all his imaginations appear to him infinitely more minutely organized than any thing seen by his mortal eye. Spirits are organized men." (Blake, $A$ Descriptive Catalogue, London I809; no. IV; Complete Writings, pp. 576 f.).

${ }_{4}$ "The visionary faculty was so much under control that, at the wish of a friend, he could summon before his abstracted gaze any of the familiar forms and faces he was asked for." Gilchrist, ed. cit., p. 263. Sometimes, however, the vision or part of it suddenly disappeared: "It rains." "It is gone." "It has moved. The mouth is gone." Ibid., p. 264. 
ascetics, and meditation and concentration techniques very often develop the faculty of seeing visions of this kind.

Eidetic phenomena are more common in children than in grown-ups, more common in primitives than in civilized men, more common in females than in males, and more common in artists than in scholars. ${ }^{1}$

They even seem to form part of the specially artistic talent. Artistic exercises - exactly as ascetic ones - tend to make the eidetic phenomena more frequent, more precise, more controlled, and more suitable as a model for artistic work. Michelangelo used to say that it is easy to make a sculpture out of a block of marble. He said, the figure is there already, the only thing you have to do, is to remove what is too much. As he could see the figure inside the stone, he was capable of working in a frenzy, without the help of preparatory sketches and marks, except those seen by his "inner eye". ${ }^{2}$

Almost any draughtsman knows about a similar phenomenon. In drawing a figure he can, after having laboriously finished the head, suddenly get the impression of seeing the whole figure already completed upon the paper. Quickly he traces the outlines - before they are gone-and the figure will be of the best quality the artist can produce, and far better than the head. ${ }^{3}$

Seeing the figure thus on the paper, is not very different from seeing it outside it. You only have to remove the vision from the place of the work to the place of the model. It is told about an English portrait painter, Wigan, that he could see his sitters after they were gone and so paint from absent models. He always saw them in the chair which they used to occupy on their first and only sitting. If somebody stepped between him and the empty chair, he asked him to move away. ${ }^{4}$ Often, but not always, eidetic pictures are located in this way to a special place.

We may safely assume that Blake's visions have an eidetic character. But

${ }^{1}$ Cf. Karl Schmëing, Seher und Seherglaube, Darmstadt I954, pp. 9 ff.

2 Blake describes etching in almost the same way: "melting apparent surfaces away, and displaying the infinite which was hid". The Marriage of Heaven and Hell, p. I4 (Complete Writings, p. I54).

${ }^{3}$ Many artists have in discussions confirmed this, and I have myself experienced the same thing.

4 Andrae, Mystikens psykologi, pp. 227, 589. The artist is called Wigan. ThiemeBecker mentions no portrait painter of that name. A similar story is fold about Richard Cosway. 
that does not explain them completely. The question whether he was a mystic or not, has as yet not been solved.

A close examination of a design drawn from a vision might help us here. About the frontispiece of Europe, the relief etching known as The Ancient of Days, found, also, in a watercolour version, John Thomas Smith tells that it was drawn from a vision of Urizen, the creator of this world, seen by Blake at the top of his staircase in his house at No. I3 Hercules Buildings, Lambeth. ${ }^{1}$ This apparition made a more powerful impression on Blake than all he had ever seen. The divine figure is drawn from in front, squatting in the sun, and setting his compasses upon the deep, preparing to draw the circle of the earth.

The subject comes from the Bible (Prov. 8:27), but Blake has taken certain details, such as the sun, and the gold of the compasses, from Milton's Paradise Lost (Book VII, line 236).

Anthony Blunt uses this very figure as evidence, when he says that Blake never saw visions, at least not in any clear and precise form. ${ }^{2}$ For there is another drawing by Blake, of the same subject, but here the figure is seen in profile. $^{3}$

Blunt concludes that Blake cannot have had any very detailed and clear vision of the figure, since he did not even know from what side he had seen it. The argument is ingenious, but at the same time profoundly absurd.

Let us imagine an artist who walks about in a town, steps into a pub, and meets a fat man who drinks beer. The artist goes home and makes from memory two drawings of the fat man, one seen from the front, the other from the side. Would we, judging from the two different drawings, venture to say that the artist had never seen a fat man drinking beer? Would we assert that the artist did not know from which side he had seen him?

Blunt forgets that visions move. And the artist moves too, on his feet and in his mind. Even if he has seen a certain visionary figure from in front

\footnotetext{
${ }^{1}$ Gilchrist, ed. cit., p. Io6, and J. T. Smith, Nollekens and his Times. London, ז 828 , p. 470 , note.

2 Anthony Blunt, "Blake's Pictorial Imagination", Fournal of the Warburg and Courtauld Institutes, VI, T943, p. 207.

3 Owned by Mrs. Ruth Lovinsky, repr. Keynes, Pencil Drawings, II, pl. 34. It is a study for a figure in Blake's small plate, There Is No Natural Religion, I788, and is thus rather safely dated that year.
} 


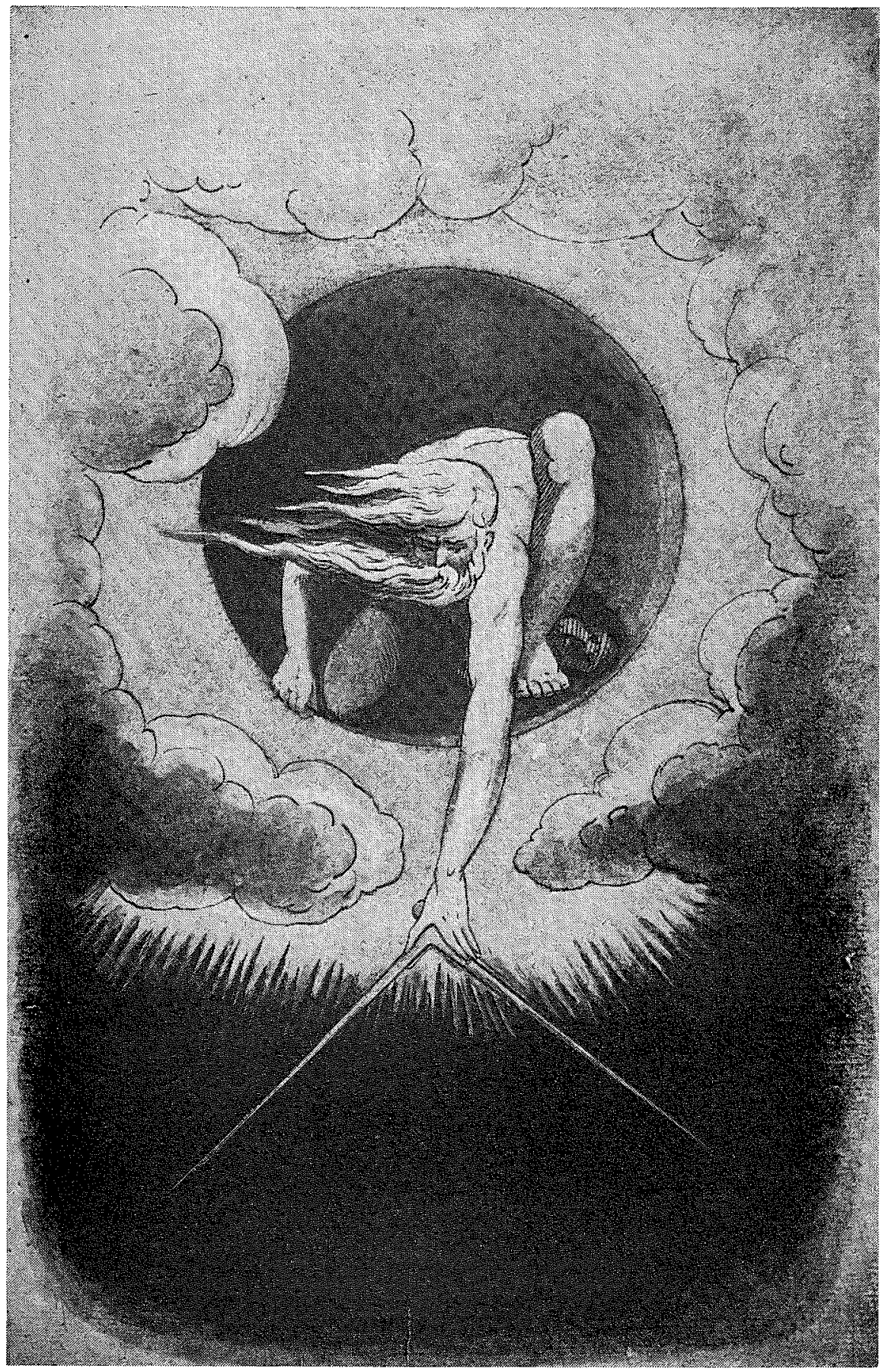

William Blake: The Ancient of Days. Watercolour. By permission of the Trustees of the British Museum. 
only, he can make a profile sketch of it, just to see what it looks like from that point of view.

But all this argumentation is useless. For the vision of The Ancient of Days was seen in Blake's house in Lambeth, where he moved in $1793 .{ }^{1}$ The reliefetching of the vision appeared as frontispiece to Blake's Europe, issued in I794. The vision is safely dated 1793 or $\mathbf{1 7 9 4}$. But the profile sketch was drawn as early as $\mathrm{I} 788$.

What, then, did Blake see at the top of his staircase in No. $r_{3}$ Hercules Buildings, some time in 1793 or $\mathrm{r} 794$ ? He saw his own drawing of $\mathrm{r} 788$, but now the figure had turned round. Blake's own creation had stepped out of the paper, and appeared to him. This happened suddenly, when Blake was standing inside his door, looking upstairs. I do not mean that Blake saw the figure at the top of his staircase; only that he saw it, as he looked up the staircase. If we could ask Blake exactly where he saw it, he would have knocked his head and said, "Here". 2

Unfortunately, we are not finished yet. For we have an impression that we have, some time before, seen the crouched figure, his arm streched down, in exactly the same way as in Blake's relief etching.

The pose is, in fact, identical with that of one of the soldiers in Michelangelo's The Battle of Cascina, which survives in engravings, i.a. by Marcantonio Raimondi. ${ }^{3}$

If we compare the Raimondi engraving, not to Blake's finished etching, but to the preparatory drawing of $1793^{-1794}$ (in the British Museum) the

${ }^{1}$ Gilchrist, ed. cit., p. 85.

2 Cf. above, p. I 45 , note 6.

"In the Bible God is called "The Ancient of Days" only by the prophet Daniel. The Ancient of Days has always been looked upon as something slightly different from God himself. The Greek orthodox icon painters, who are forbidden to paint God, include The Ancient of Days in their compositions of Paternity, the eastern equivalent of the western Holy Trinity. The cabbalists interpreted The Ancient of Days as the Demiurg of the Greeks, and used as a symbol for him the Fupiter Pluvius, from the Marcus Aurelius column. Blake used this $\mathscr{F}$ upiter Pluvius in a drawing, partly after Fuseli, executed in I79I; and later it became one of his standard pictorial signs, as Blunt has pointed out, The Art William Blake, p. 4I. Blake interpreted The Ancient of Days as Urizen, the Demiurg of The Book of Urizen and The Book of Ahania. Several coloured versions of Blake's relief etching of The Ancient of Days are known. 


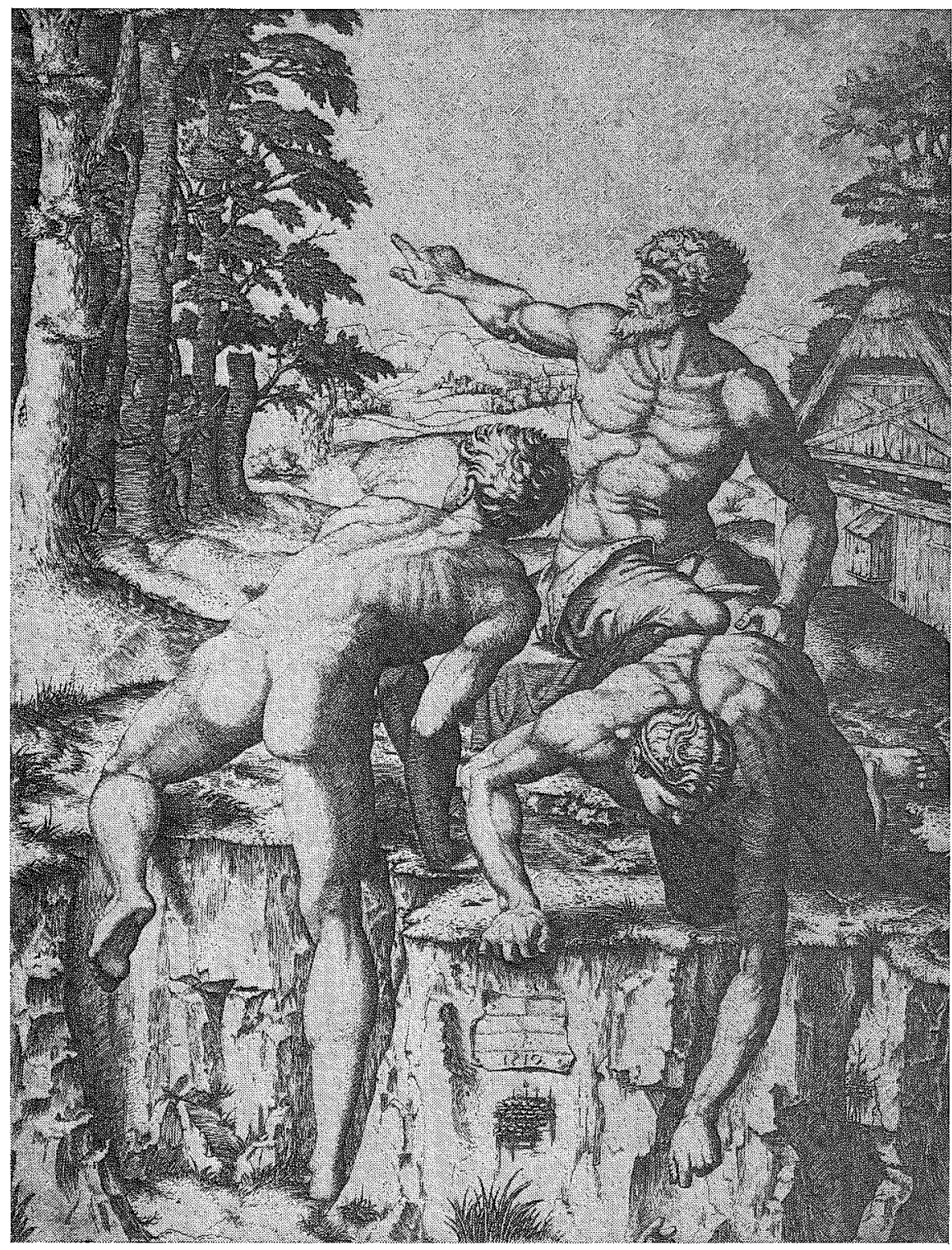

Marcantonio Raimondi: Engraving after Michelangelo's The Battle of Cascina. By permission of the Trustees of the British Museum. 
parallel is complete. ${ }^{1}$ In the sketch Blake shows the right arm of the man, in exactly the same pose as in Marcantonio's engraving. This arm is omitted as unnecessary in the final design.

The pose in itself is almost as old as humanity; as long as people have filled buckets with water, it has been an everyday sight. But the pose is very rare in art; indeed, the artistic formula for it seems to have been invented by Michelangelo.

So what did Blake see in his vision of The Ancient of Days? He saw his own God the Creator of 1788 , turned round and posing as the soldier of Marcantonio, and furnished with the red sun and golden compasses of Milton's Paradise Lost. Features from two literary sources (the Bible, Milton) and two pictorial sources (Blake's own drawing, Marcantonio's engraving) are united in the vision of Urizen, The Ancient of Days. Blake has added a few details, the most significant of which are the hair and beard, blowing in some cosmic wind, and the position of the left foot and knee.

Exactly in the same way ordinary non-visionaries can see, in dreams, figures built up by elements from different sources. Such a creation is not, as an artistic invention, dependent upon the sources from which it is built up; a builder is honoured as the creator of the house, even if he has not made the bricks himself. Such a creation should not be dismissed as a copy. ${ }^{2}$

Blake drew The Ancient of Days from memory, and not from "life", not with the spiritual sitter before his eyes, as in the case of the visionary heads. Blake used his visions as other artists use nature. He could draw spiritual sitters "from life", he could draw spiritual appearances from memory, or he could compose pictures which resembled what he had seen in vision, although not being faithful copies of any single vision.

1 The authenticity of the drawing in the British Museum Print Room is not undisputed, and the BM includes it among "copies". No reason for this is given, except its rather poor quality. It must be remembered that many of Blake's original works are of an uneven quality. If the BM drawing is a copy, why does it show the additional arm? I think it can be safely included in Blake's ouvre. There is, also, another sketch for it, drawn in pencil c. I793 in Blake's Note-book, BM, MS 49460 , p. 90 .

2 Michelangelo himself copied the figure 40 years later, when he executed one of the blessed in the Last Yudgment. Blake used Michelangelo's second version in The Book of Urizen, $\mathrm{pl} \mathrm{I}_{4}$, and in the title-page of his Visions of the Daughters of Albion, and in pl. 15 of the $\mathcal{F o b}$. A different version is found in the margin of $\mathcal{F e r u s a l e m}$ p. I2. 
The two apotheoses of Pitt and Nelson are examples of the latter category. Blake writes in his Descriptive Catalogue:

The two Pictures of Nelson and Pitt are compositions of a mythological cast, similar to those Apotheoses of Persian, Hindoo, and Egyptian Antiquity, which are still preserved on rude monuments, being copies from some stupendous originals now lost or perhaps buried till some happier age. The Artist having been taken in vision into the ancient republics, monarchies, and patriarchates of Asia, has seen those wonderful originals called in the Sacred Scriptures the Cherubim, which were sculptured and painted on walls of Temples, Towers, Cities, Palaces, and erected in the highly cultivated states of Egypt, Moab, Edom, Aram, among the Rivers of Paradise, being originals from which the Greeks and Hetrurians copied Hercules Farnese, Venus of Medicis, Apollo Belvidere, and all the grand works of ancient art. They were executed in a very superior style to those justly admired copies, being with their accompaniments terrific and grand in the highest degree. The Artist has endeavoured to emulate the grandeur of those seen in his vision, and to apply it to modern Heroes, on a smaller scale. ${ }^{1}$

The contents of Blake's visions, like the contents of any man's dreams, are composed of material from his daily life and daily thoughts. Looking at paintings and engravings formed an essential part of Blake's life. It is quite natural that figures from paintings, sculptures and engravings-real and imagined-should inhabit the visions of Blake.

But still we do not know if Blake really was a mystic; all visionaries are not. Eidetic phenomena or other visions alone are not enough to make a man a mystic. Visions without the mystical union with God, are just visions.

If we examine Blake's set of engravings for the Book of Job, we might perhaps get an answer. Blake's interest in the Book of Job is in itself an indication of his interest in mysticism. ${ }^{2}$ Job was a man who became a mystic

${ }^{1} A$ Descriptive Catalogue, no. II (Complete Writings, p. 565).

2 Blake's illustrations of the Book of $\mathcal{F}_{0 b} b$ amount to at least 137; and then I exclude the 22 watercolours in the so-called New Zealand set (owned by Paul Mellon), which seem to be copies painted after Blake's death by Albin Martin in collaboration with John Linnell; furthermore I exclude the four coloured engravings in the Fitzwilliam museum, in which the handling of the watercolour is not very Blake-like; and the tempera paintings of Pitt and Nelson, which are only partly related to Job the monsters Behemoth and Leviathan are taken from the $B o o k$ of $\mathfrak{F} o b$ ); and I exclude all early states of the engravings, many of them pencilled by Blake; and the so-called Head of $\mathcal{F} o b$ (Geoffrey Keynes) which seems to be a study for the head of Ezekiel in the engraving The Death of Ezekiel's Wife I 794 (the drawing must be dated I79394, and not, as Keynes supposes about 1825); and the lithograph of Enoch, formerly called $\mathcal{F}_{o b}$ and a large watercolour listed by Keynes, Satan Before the Throne of God, which is a doublet of the early watercolour fob and his Family. Blake's Job illustra- 
by suffering. The afflictions to which he was subjected by Satan take the place of the ascetic exercises of mystical tradition. His sitting on a dunghill, ${ }^{1}$ his seven days' silence, and his penetrating discourses to his friends and to God can be compared to the contemplation and concentration techniques of the mystics. All through the dialogues Job tries to force God to answer him reasonably; he seeks for a justification of the ways and counsel of God, which his intellect can understand. How can the God of justice permit the sufferings of a righteous man?

But when God finally appears he answers none of Job's questions. He just shows himself to Job, praising his creation and ordering Job so sacrifice for the benefit of his false friends.

tions include two sets of watercolours of $2 \mathrm{r}$ drawings each (the Pierpont Morgan Library, New York and the Fogg Art Museum, Harvard), a book of 22 engravings, a set of 22 coloured engravings, 27 sketches in pencil and watercolour in the Fitzwilliam Museum, Cambridge, a pencil sketch for the title-page (N.G.A., Washing-

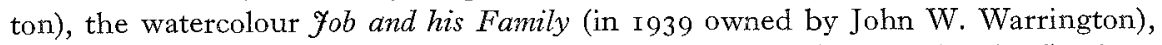
the watercolour The Lord Speaking to $\mathcal{F}_{o b}$ (National Gallery of Scotland), three versions, among them a tempera painting of $\mathscr{F}_{o b}$ and his Daughters (one deposited in the Tate, two in the N.G.A., Washington), two separate drawings of Everyone Also Gave Him a Piece of Money (British Museum, Mr. Kerrison Preston), a watercolour of Fob's sacrifice (The Leeds City Art Gallery), a sketch of Satan for pl. 4 of the engraved set (Geoffrey Keynes), the tempera painting Satan Smiting $\mathcal{F}_{0}$, (Tate Gallery), two engravings in The Gates of Paradise (the frontispiece quotes Job $7: \mathrm{r} 7$ and no. I6 Job r7:I4); and three pencil sketches in Blake's MS Book in the British Museum MS 4946o, for the Gates of Paradise, pp. 45, 48; one, on p. I7, quoting Job $3: 22$; the two very different states of the engraving $\mathcal{F}_{0} b, 1793$; and six sketches for it (one in the BM Note Book, MS 49460, p. 20; two in the Tate, two with unknown owners-sold at Sotheby's, Dec. I7th I928, lot $\mathrm{r}_{3} 8$, and Nov. r8th I953, lot $122-$ and one owned by 'T. Edward Hanley). In his literary works, Blake quotes the Book of $\mathcal{F}_{0 b}$ i.a. in The Marriage of Heaven and Hell, in a letter to Thomas Butts of Jan. roth $\times 802$, and in Ferusalem, where Albion's fall, sickness and recovery are copied from the story of Job; here Blake uses the story of Job as an emblem of the fate of mankind as a whole.

1 The Authorised version has "ashes" in $\mathcal{F}_{o b}$ 2: 8, and so has the Revised version. Blake, however, depicts Job sitting on a dunghill, as in the Vulgata. He is working out of the pictorial tradition established in old Christian times and continued through the medieval centuries and the renaissance down to the protestant artists of the modern age. The translation of the Vulgata is the correct one; all modern Bibles are wrong on this point. In the east people smitten with catching diseases were expelled from the community, and had to live on the huge dunghill outside the village or town, a tradition continued into the beginning of the zoth century. The dung was oftentimes burnt; therefore many semitic languages have the same word for "ashes" and "dung". Cf. H. L. Ellison, From Tragedy to Triumph. The Message of the Book of $\mathscr{f} o b$, London r958, pp. $26 \mathrm{f}$. 
And Job says, "Now mine eye seeth thee", and is satisfied. ${ }^{1}$ At this moment Job's body is still covered with boils, his children are dead and his riches gone. While he had not yet seen God he was thinking of nothing but his own agony; now, though his state is as low as before, his lamentations cease. He has seen God, and forgets all his sufferings. He praises God, forgives his friends, and, when that is done, is restored to prosperity.

To Blake, the central theme of the book was Job's development into a mystic. This is reflected in the very composition of the Job series. In the first design the sinking sun illustrates the darkening of spiritual light in Job's soul. ${ }^{2}$ Job is worshipping the letter that killeth, as a marginal quotation says. ${ }^{3}$ The sinking sun is repeated in pl. 6, were Satan gets complete power over Job, and stands triumphantly on the stomach of the patriarch, who lies on the ground. ${ }^{4}$ From now on the night sky is darkening from plate to plate, till the turning point comes in plate $\mathrm{I}$, where Job in his midnight dreams is left alone with his demon-god, who points at a law of stone and a punishment of hellfire. ${ }^{5}$ In plate 12 the stars give light in the sky. In plate I3 God appears, and in plate 16 Satan is defeated in a last judgement, while the halo of the Deity shines like a sun. In plate 2I, Job is shown praising the spirit that giveth life, while the sun rises. ${ }^{6}$ The composition of the pictorial narrative can be expressed graphically as a half-circle, with pl. II as its lowest point:

1 7ob $42: 5$.

2 Charles Eliot Norton, William Blake's Illustrations of the Book of $\mathcal{F}$ ob, Boston I 875 , is the first to note that the sun is sinking (comment on pl. I), but he does not understand the sun as an emblem of the Spirit. Joseph. Wicksteed, Blake's Vision of the Book of $\mathcal{F} o b$, London I9IO, 2nd ed. I924, p. 9o, interprets it as Job's soul, which is not exactly the point. See also below, note 4 .

3 "The Letter Killeth The Spirit giveth Life" (2 Chor. 2:14).

4. Wicksteed, ed. cit., p. I26 interprets the sun in pl. 6 as the soul of Job's wife, which is not very probable. The sun illustrates, I think, the same darkening of the spiritual light in Job's soul, as in pl. I of the Job series.

5 The cloven hoof identifies him as Satan. At the same time he is God; we can see how in pl. 5 God's hair is beginning to assume the tossed appearance, seen fully developed in pl. I I. In the Bible ( $\left.\mathscr{F} \circ b_{7: 14}\right)$ Job's evil dreams are none of his worst afflictions, and their contents are not described. Here they are the turning-point of the pictorial epic; and represent at the same time Job's worst affliction and the beginning of his recovery.

6 Cf. above, note 3 . 


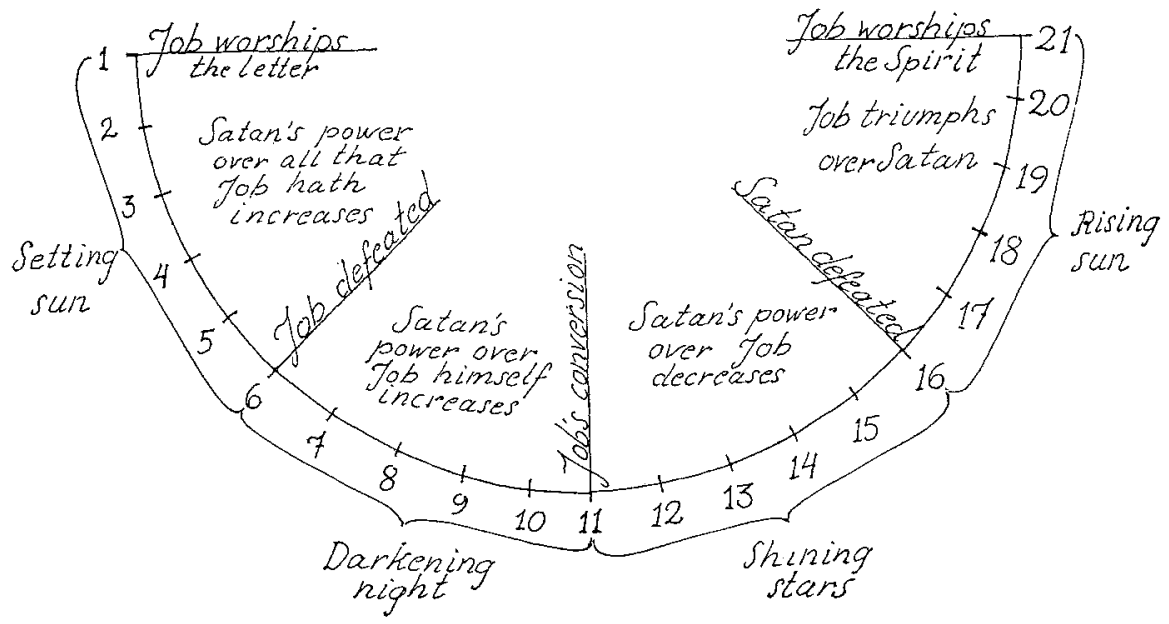

In mysticism, two conceptions of God exist side by side; he is a God beyond human understanding, a God without qualities, and at the same time he is something that man can see with his own eyes, a brother and friend, a man like you and me. In the first part of Blake's Job story God is neither unapprehensible nor a brother and friend, he is a crowned tyrant, who first opposes Satan, and then (in pl. II) is united with him. ${ }^{1}$ The second part opens with the words of Elihu, a discourse of God the unapprehensible, ${ }^{2}$ and continues with quotations from St. John, where the oneness of God, Christ and Man is exposed (pl. I7) ${ }^{3}$. The scenery reflects this spiritual evolution; in the first part it is shown in great topographical detail, but in the second part it is suppressed in favour of light, clouds, fire, human, angelic and divine figures, and paintings and visions. Thus Blake shows us matter spiritualised; he gives us the pictorial formula for the universe transfigured into Grod, a truly mystic conception.

This is clearly shown in pl. I 7 where the united God-Jesus has descended upon earth, with clouds from the heavenly regions still hanging from his feet.

${ }^{1}$ Hagstrum correctly observes the struggle between the Urizenic and Jesusean Gods in Job's heaven. Cf. Jean Hagstrum, William Blake, Poet and Painter, Chicago etc. I964, Chap. IX, pp. II9 ff.

${ }_{2}$ "Look upon the heavens that are higher than thou" ( $\mathscr{F}_{0 b} 35: 5$ ); "If thou sinnest what doest thou against him or if thou be righteous what givest thou unto him" (Job 35:7); these are among the quotations engraved by Blake in the margin.

3 Several quoted from $\mathcal{F}_{0 h n} \mathrm{I} 4$, and one from $\mathfrak{F}_{\mathrm{ohn}}$ 10:30. 


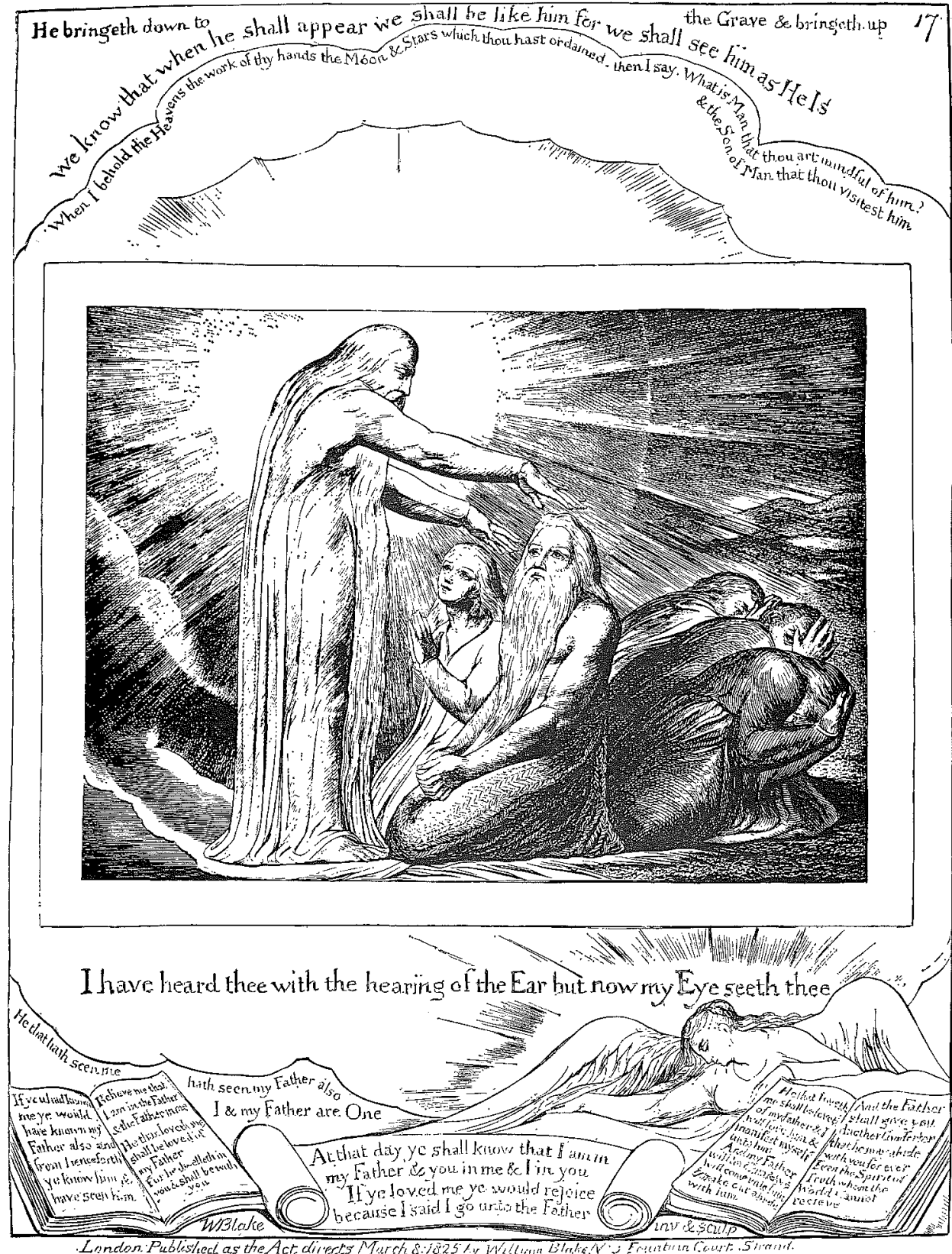

William Blake: Now my Eye seeth thee. No. I7 of Blake's set of 21 engravings for the Book of Job. By permission of the Trustees of the British Museum. 


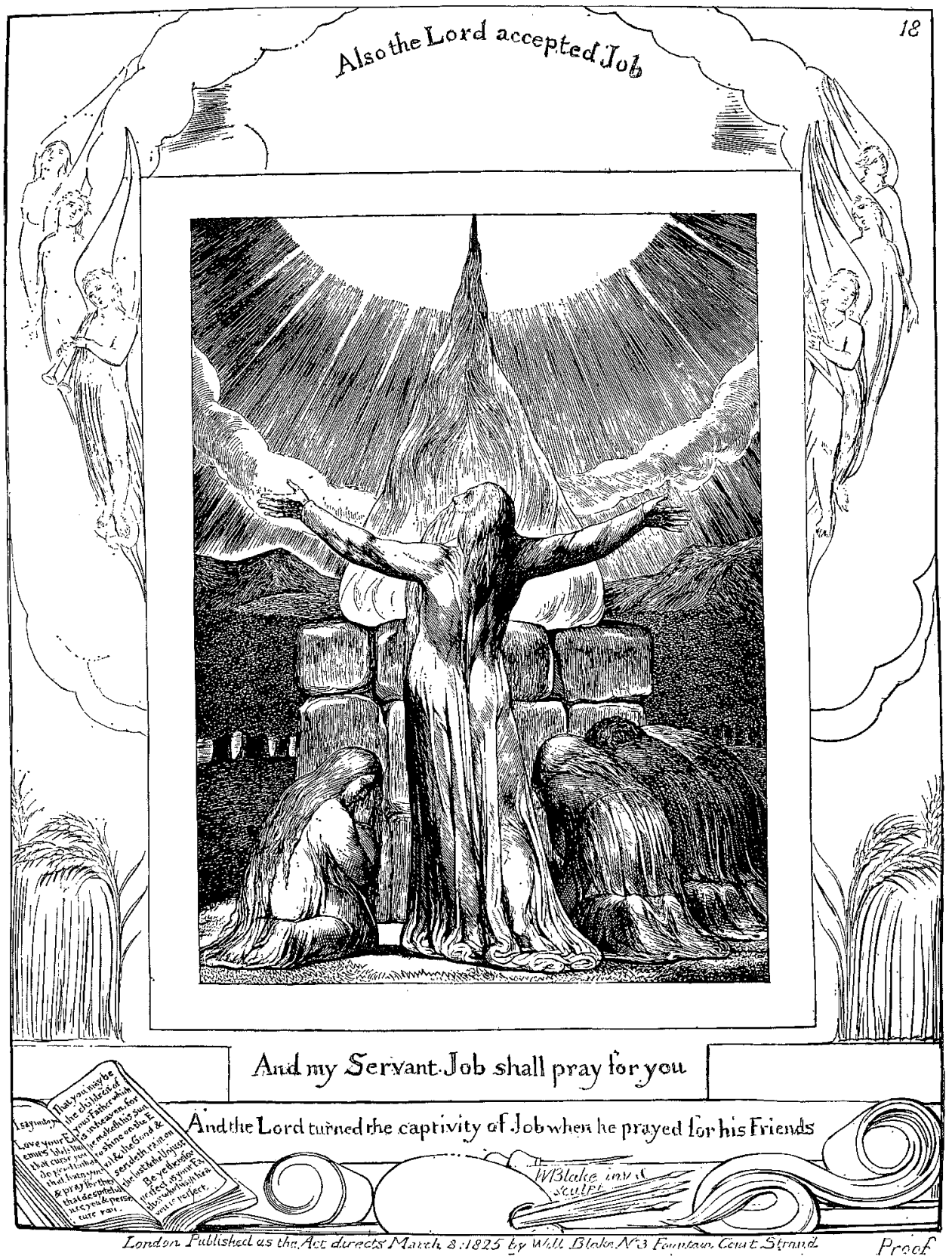

William Blake: Job's Unio Mystica. No. I 8 of Blake's set of engravings for the Book of Job. By permission of the Trustees of the British Museum., 
Below his feet earth is transformed into air (though the horizon on the right shows that he must be standing on solid ground).

Plate I 8 is a perfect emblem of the unio mystica. Job turns his back on this world (in art, the back view generally means the turning from outward to inward things, from the world to God $)^{1}$ embracing the light of the sun. This sun must be identical with the halo of God in pl. $\mathbf{x} 7$, anyway, it is God.2 The fire of Job's burnt offering soars upward, until the top of it hits the centre of the sun, the light of which fills the whole world of Job. The friends crouch in the shadow of the material stones of the altar, and are united with the Spirit only by Job's forgiving their transgressions. Notice, that the bearing lines of the composition all reflect either the rays or the circumference of the spiritual sun; matter is organised according to the movement of the Spirit. The margin shows a palette, painter's brushes, and burins; the unio mystica is also an artistic rebirth.

In the last plate the result of divine inspiration is shown. Job and his family have taken down the musical instruments from the branches of the oak, and praise God in music and song in the sunrise. The sun should not be looked upon as a symbol of God or the spirit, it is the sun, transfigured into a spiritual being:

“' 'What', it will be Question'd, 'When the Sun rises, do you not see a round disk of fire somewhat like a Guinea?' O no, no, I see an Innumerable company of the Heavenly host crying 'Holy, Holy, Holy is the Lord God Almighty', I question not my Corporeal or Vegetative Eye any more than I Question a Window concerning a Sight. I look thro' it \& not with it."'s

These words by Blake are quoted here because they, like the ending plates of Job, express what the catholic visionaries call the intellectual vision,

1 The same pathos-formula is used by Blake in p. 76 of the ferusalem, of Albion before the crucified Christ; in The Sacrifice of Noah (1799) and The Sacrifice of Fephtah (1803). In art it is used to show people who turn their backs on the world, who pray or have visions, as in H. S. Beham's Lex Datur in Monte Syna, were Moses, turning his back on the spectator, faces God, depicted as a sun; see Biblicae Historiae, ed. Christian Egenolph, Frankfurt a.M. 1539, Exd. XIX (unpag.)

${ }_{2}$ The sun is generally conceived as an emblem of God, and, especially, of Christ. The sun as mentioned by God in the Book of $\mathscr{f}_{o b}$ is "the emblematical and material representation of the Second Person in the Deity", writes Walter Hodges in his Elihu, Oxford, 1750, p. 84. In Albrecht Altdorfer's woodcut of The Resurrection, Christ is encircled by a sun. Cf. Matthew 17:2 "and his face did shine as the sun".

s "The Last Judgment", Note-book (British Museum), p. 95; Complete Writings p. 617. 
the highest kind of vision, cleansed from the hallucinatory bodies and eidetic pictures, and seeing nothing but natural things, but all these overflowing with spiritual agency. ${ }^{1}$

Blake's Job was a visionary and a mystic. But was the Job series, like the visionary heads, copied from vision? ${ }^{2}$

There is a reliable statement intimating divine inspiration for the Job series. It is found in the hieroglyphic signature, applied by Blake below the sketch for pl. I4 in the Job series:

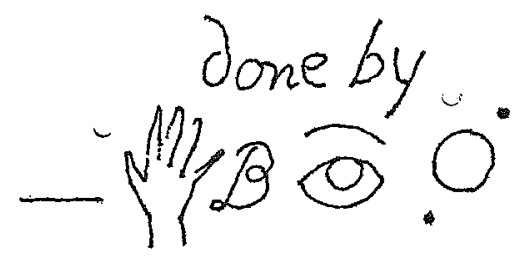

Keynes and Wicksteed have tried to decipher the signature. They compare it to the opening lines of Blake's The Tyger, and interpret the straight line as eternity, the circle as symmetry, and the hand and the eye as the immortal hand and eye of God or the Poetic Genius. ${ }^{3}$ The B is, of course, the monogram of Blake. There is a defect in this explanation, it cannot make the hieroglyph a meaningful whole. Which is the relation between the parts, what is the message hidden in the signs?

Let us examine the signature closer. The eye is looking upwards, the hand is pointing upwards. Consequently they cannot be the hand and eye of God.

1 This kind of vision is akin to the transfiguration of St. John of the Cross. Cf. Andrae, Mystikens psykologi, p. 216.

2 In the false interview, published in the Revue Britannique, July, I 833 (cf. above, p. I4I, note 2). Blake, a patient of Bedlam, is made to say: "J'ai vu le pauvre Job avanthier: il n'a voulu rester que deux minutes; j'ai à peine eu le temps d'en faire une esquisse que j'ai ensuite copié à l'eau forte ... Mais chut ... voici Richard III!' (p. 72). All this is distorted from a biographical sketch in the Monthly Magazine of March I833: "One night, while he was engaged in criticizing his own extravagant, yet occasionally sublime illustrations of the Book of Job engraved by himself, he suddenly exclaimed, 'Good God! Here's Edward the Third!' " Blake was, of course, never in Bedlam or in any other madhouse: cf. William T. Horton, "Was Blake ever in Bedlam?", Occult Review, London Nov. I912, pp. 266-299. The impossibility of the Revue Britannique article is shown in the statement that Blake had engraved his Job from a sketch drawn the day before yesterday. Nobody can believe that - unless he knows nothing about engraving on copper.

${ }^{3}$ Geoffrey Keynes, Blake Studies, London, I949, pp. I48 f. 
For why should God look upwards; there is nothing higher than he. In art, the hand and eye of God is shown pointing and looking down, especially when one of these organs is used as a sign for God as a whole. ${ }^{1}$

We have to do with a mortal hand and eye, Blake's. They also stand on each side of the letter $\mathrm{B}$ (=Blake). The circle with a point on either side looks very much like the earth globe surrounded by the sun and the moon, as they are represented in the margin of the final, engraved design. The line is an accepted, although not common symbol of infinity; Keynes and Wicksteed seem to interpret this part of the hieroglyph correctly.

If this argument is accepted, the interpretation of the hieroglyph is as follows: B (Blake) represented by the most important organs of an artist, the hand and the eye, is placed between the infinite spiritual world and the finite natural world. The eye is looking upwards, at the immortal visions of God (which appear in the drawing above the signature), and the hand is working in accordance with these visions. The signature tells us that pl. I4 of the Job series is done by a draughtsman and visionary, inspired by a divine vision. It could be called a door from this world to eternity, pushed open by the artist Blake.

We understand that Blake had much in common with the mystics. His conception of God is of a mystical character, and so are his visions. $\mathrm{He}$ viewed them as messengers from eternity. ${ }^{2}$ He never tried to explain them in natural, psychological terms, and he never boasted of them; on the contrary, he thought that any man could have visions, if he just opened his inward eyes, by art and prayer. ${ }^{3}$

Many writers have called Blake a mystic; others have denied it. ${ }^{4}$ As to

${ }^{1}$ If the whole figure of God is shown he can-if seldom-look upwards. But this always means that God has descended upon earth, and looks upwards, at the heaven from which he is come, as is the case in pl. I4 of Blake's $\mathcal{F o b}_{0}$

2 Cf. below, p. 165 , note 1 .

${ }^{3}$ Blake taught his wife to see visions - and to read, write, draw, paint, and handle the copper press, cf. Gilchrist, ed. cit., p. 315. Blake used to tell his artist friends: "You have the same faculty as $I$ (the visionary), only you do not trust or cultivate it. You can see what I do, if you choose!" The italics are Gilchrist's, ed. cit., p. 3 I 8.

${ }^{4}$ Helen $C$. White searches in vain the pages of Blake "for the beauty that passes understanding" and says that he was not a mystic, at least not a great one, The Mysticism of William Blake, 1964, p. 211 . She might perhaps have found it, had she searched his paintings and drawings. "... it is much safer not to call him a mystic at all", says Northrop Frye, Fearful Symmetry, p. I07. Blake was not a 


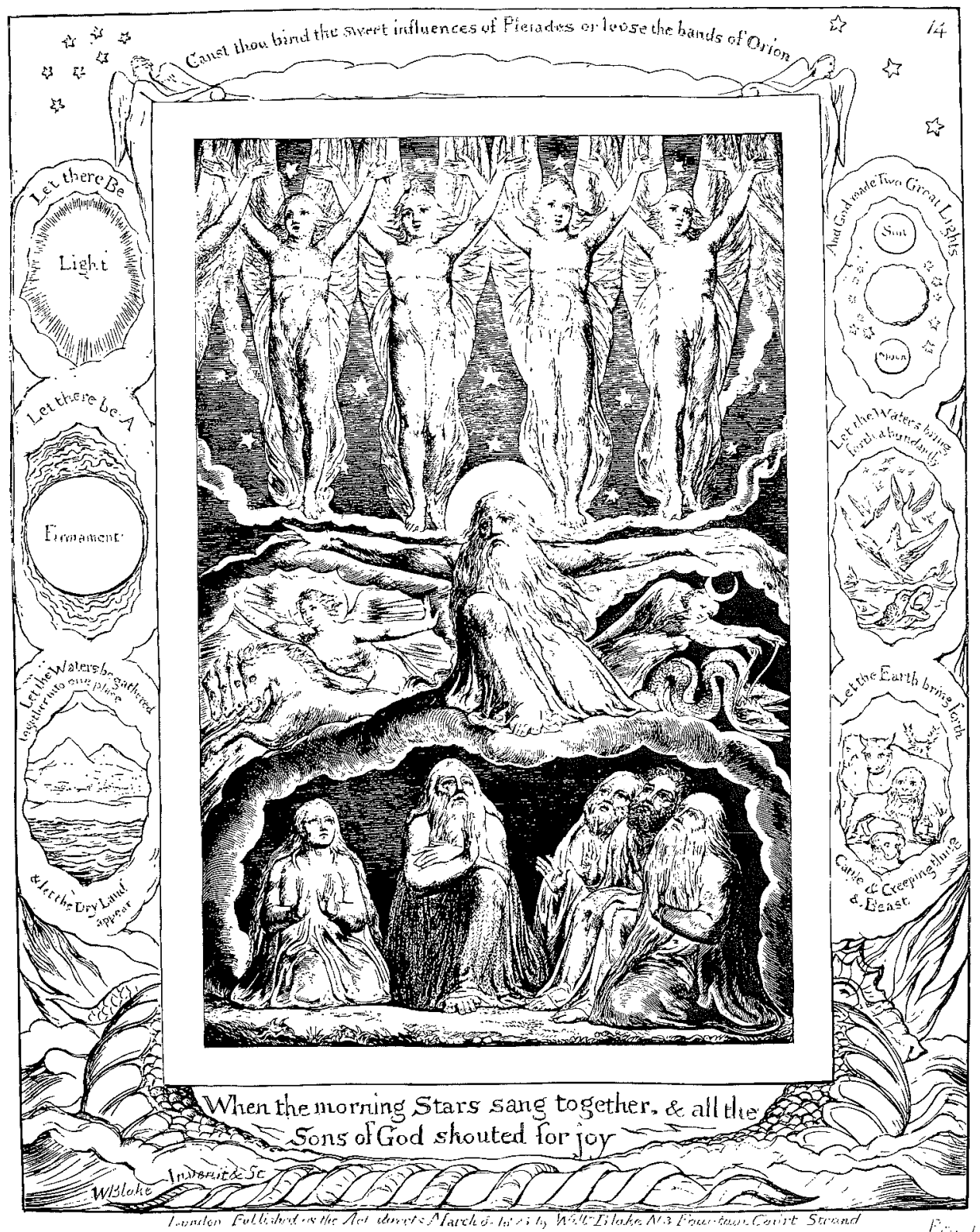

William Blake: God Praising his Creation. No. I4 of the Job set. By permission of the Trustees of the British Museum. 
the definition of a mystic, opinions differ. There seems to be no positive characteristic, present in all men generally called mystics, and absent from all others. We cannot draw a line between the mystic mind, and the nonmystic religious mind. Not even the non-religious mind can be excluded from discussion; an atheist can be a mystic. ${ }^{1}$ So, without being able to tell

mystic, according to John Theobald, "Was Blake a Mystic", Personalist, I956, pp. 47 ff. S. Foster Damon, on the other hand, calls Blake a mystic. He finds in Blake's life the five mystic stages, described by Evelyn Underhill as characteristic of the mystic's way of life, Damon, A Blake Dictionary, I965, pp. 29I $\mathrm{f}$. It can be disputed, whether these stages really are found in Blake's life, in the sense Underhill understood them, and it can moreover be disputed if the five stages can be used as a definitive criterion of mysticism. Evelyn Underhill, anyway, denies that Blake was a mystic, and calls his visions "corporeal", not "imaginary"; Underhill, Mysticism, A Study in the Nature and Development of Man's Spiritual Consciousness, London I9I I, p. 335. Lafcadio Hearn, Interpretations of Literature, London I9 16, pp. 5 I ff., calls Blake the first English mystic, and Caroline F. E. Spurgeon, Mysticism in English Literature, Cambridge I912, p. I I, says that Blake is the only English mystic, except Wordsworth. Among those who have been interested in Blake's mysticism are P. Berger, William Blake, Mysticisme et Poésie, Paris 1907; Jaecmina Korteling, Mysticism in Blake and Wordsworth, Paris 1928; Maung Ba-Han, William Blake, His Mysticism, Bordeaux 1924, and Jacques Roos, Aspects Littéraires du Mysticisme Philosophique, Strasbourg, 195 I, "William Blake", pp. 25-I94. All of these are rather unsuccessful in their definition of mysticism, which seems to include too much; and Roos is ignorant of modern Blake scholarship; his book $i$ written as if it had appeared in 1930 instead of $195 \mathrm{I}$.

1 Mysticism, I think, is best described as a conception with a centre but without limits; as a mass diffusing around a compact middle. We can, by the conventions of language, determine which persons should be called the "great" mystics, the "central" mystics; all agree on Theresa and St John of the Cross. Out of the governing ideas of such mystics, we can tell what "typical mysticism" is. But on the other hand mysticism diffuses roundabout into other fields of religion and life. It could be compared to the geographic problem of the undetermined border. The border, say, between Finland and Russia in the 15 th century was lost somewhere in the forests north of lake Ladoga. No one could say exactly where it was. But the central parts of the countries were known, and their inhabitants, agriculture, trading, laws and rulers; and the names Finland and Russia were, consequently, verbally meaningful conceptions. There are conceptions which cannot be defined in the ordinary way, by describing the limits; instead, any reasonable definition must try to catch the centre. There is a theory of such conceptions, included in Wittgenstein's theory of family resemblance, according to which things with no qualities in common can be gathered into the same group by a series of qualities found in other objects. The first thing has, for instance, the qualities $a b c d$, the second $c d e f$, and the third efgh. Abcd and efgh have no qualities in common, but are related to a group of family resemblance, by the $c$ def. Art is a conception of this kind, and, I think, mysticism too. The conception is built up of qualities, included in a series of objects, called objects of art-or works of mysticism. But one objection can be made: there is a distinctive quality in mysti- 
exactly what mysticism is, we have to answer the question whether Blake was a mystic or not.

This would be quite impossible, if we did not know about certain characteristics, which, though not the sole property of the mystics, are more common in them than in other men: the ascetic exercises, the denial of this world, the experience of divine inspiration, the visions and auditions.

All of this is found in Blake. Even the ascetic exercises have their counterpart in Blake's artistic toil. The engraving of Blake's poems-of which the Ferusalem alone amounts to 99 pages - letter by letter and design by design, in reverse upon copperplates, is a labour worth many fastings and hair shirts. Blake was an ascetic of artistic labour and prayer. ${ }^{1}$ Otherwise he ate and drank normally as did our Lord, says the Bible; and he had a wife, like Ezekiel.

Most mystics tell us that they cannot describe the mystic experience, the vision, the unio mystica. However many and well chosen the words, they

cism, the unio mystica, the union with God. The formula describing the works of mysticism will be: $a b c d x, c d e f x, e f g h x$, where $\mathrm{x}$ (=the unio mystica) is common to all. But this $\mathrm{x}$ is in itself indescribable, and cannot be used in a verbal definition; we do not know if this $\mathrm{x}$ is the same as other $\mathrm{x}$ :es of our life, or something else. It belongs to the things of which Wittgenstein said that we cannot talk about them, but must be silent. In art, too, such an $\mathrm{x}$ is found: constituting the expression of verbally indescribable human experience. This $\mathrm{x}$ we cannot talk about either: the $\mathrm{x}$ cannot fix the limits, because it is an element devoid of verbal meaning. Wittgenstein justly excludes it from his theory of family resemblance. We must conclude that Wittgenstein's theory and the problem of the undetermined border can help us to understand the centre of mysticism, and gather qualities, such as the presence of ascetic discipline, visions etc (the a:s, b:s, c:s etc. of Wittgenstein's theory), which usally but not always belong to it, as the word is used in speech and writing. If two men are of a different opinion, whether some person should be called a great and central mystic, or no mystic at all they do not speak the same language, or else one of them is definitely wrong. But as to the border cases, their inclusion or exclusion must always remain a matter for discussion. We might ask, is the precense of the quality $f$-which is found in some but not all central examples of mysticism-enough to give us the right to call the owner of $f$, or all owners of $f$, a mystic? Such questions must be settled from one case to another. Perhaps the best thing with Wittgenstein's theory is that it does not pretend to give a general answer to such questions. - As to the atheist mystic, the experience of union with cosmos or nature is not easily distinguishable from the union with God.

${ }^{1}$ Young George Richmond, who felt once deserted by the power of invention, related his distress to Blake. Blake turned to his wife: " 'It is just so with us, is it not, for weeks together, when the visions forsake us? What do we do then, Kate?' 'We kneel down and pray, Mr. Blake." " Gilchrist, ed. cit., p. $3^{\circ 0}$. 
cannot give any proper idea of the union with God. Here we find the central conception of mysticism, but we do not know what it is. Or, more properly, we have not the words to talk about it.

But Blake says that he can copy imagination more correctly than anyone can copy nature - and by imagination he means the Divine Vision. ${ }^{1}$ Apparently he is thinking of all visions, even those containing what seems to be a unio mystica, like that depicted in pl. I 8 of the $y_{o b}$, and pls. $7^{6}$ and 99 of Ferusalem. Blake never said that there was anything obscure in his visions (the models) or his art (the copies of his visions). Blake writes, in his Descriptive Catalogue:

"The connoisseurs and artists who have made objections to Mr. B.'s mode of representing spirits with real bodies, would do well to consider that the Venus, the Minerva, the Jupiter, the Apollo, which they admire in Greek statues are all of them representations of spiritual existencies, of Gods immortal, to the mortal perishing organ of sight; and yet they are embodied and organized in solid marble. Mr. B. requires the same latitude, and all is well. The Prophets describe what they saw in Vision as real and existing men, whom they saw with their imaginative and immortal organs; the Apostles the same; the clearer the organ the more distinct the object. A Spirit and a Vision are not, as the modern philosophy supposes, a cloudy vapour, or a nothing: they are organized and minutely articulated beyond all that the mortal and perishing nature can produce. He who does not imagine in stronger and better lineaments, and in stronger and better light than his perishing and mortal eye can see, does not imagine at all. The painter of this work asserts that all his imag inations appear to him infinitely more perfect and more minutely organized than any thing seen by his mortal eye. Spirits are organized men."'

These visions Blake articulated pictorially, and the corresponding auditions verbally. And all articulations, Blake thought, were minutely detailed, correct copies. ${ }^{3}$ The central conception of mysticism, the personal experience of the presence of a divine power, unapprehensible and inexplicable, seems never to have entered Blake's mind. Did his visions contain any unio mystica? Was Blake no mystic at all?

1 "Men think they can Copy Nature as Correctly as I copy Imagination; this they will find Impossible." Note-book, BM, p. 59 (Complete Writings, p. 594); “One Power alone makes a Poet: Imagination, The Divine Vision", marg. to Wordsworth (Complete Writings, p. 782); "The Divine Image or Imagination". "Imagination is the Divine Body in Every Man", marg. To Berkeley's Siris, pp. 205, 204 (Complete Writings, p. 773).

a Descriptive Catalogue, no. IV (Complete Writings, p. 576 f.).

${ }^{3}$ Cf. above, note $\mathrm{r}$. 
He was. For what the mystics say, is that their vision of God, their unio mystica, cannot be described in matter of fact prose. They say that it cannot be described so that those who have not already had a vision would understand, from the description, what a vision is. But Blake is not talking about matter of fact prose description. He is talking about art.

Anyone who has tried to describe a picture in words has found that there remains something in the picture, which words cannot tell. There seems to be some sort of human experience which cannot be articulated, but in lines, colours and masses. The articulation of this experience we would like to call the proper realm of the pictorial arts. This is the art in art. When pictures talk about it, they are speaking their mother tongue. This art in art cannot be defined in intelligible words, for its nature is such, that it can be caught by the language of the pictorial arts only.

The same is true about any written text of artistic significance. If we try to write down, in plain prose, what Coleridge's Khubla Khan is all about, we might write 30 pages or 300 or 3000 ; and still be unable to tell what in the poem makes us read it so closely and write about it so much. Notice; we feel that we know why, but we cannot explain it except, perhaps, in a painting or in another poem.

There is something in man, which cannot be described, except in art, poetry and music. If it were not so, we would not need the arts. If it were not so, we could tell what art is, and leave it.

There is, as we can see, an inexplicable element in art, and this element is the very essence of art. We can talk around it, but not about it. In this respect art is not very different from mysticism. Blake thought they were the same thing:

A Poet, a Painter, a Musician, an Architect: the Man Or Woman who is not one of these is not a Christian. Prayer is the Study of Art. Praise is the Practise of Art. Fasting \& c., all relate to Art. Jesus \& his Apostles \& Disciples were all Artists. The Old \& New Testaments are the Great Code of Art. Art is the Tree of Life. God is Jesus. ${ }^{1}$

When Blake says that he can copy his visions correctly, he says nothing contradictory to the mystics, when they confess that their visions defy

\footnotetext{
${ }^{1}$ Aphorisms from Blake's Laocoon (Complete Writings, pp. 775 f.). Blake is talking about Christianity, not mysticism; but Christianity was, to Blake, a mystical faith.
} 
description. They are talking about intelligible, one-dimensional reasoning prose, and he about art.

Vision and prose have nothing to do with each other, but vision and art have. To Blake art was a vision of the spiritual world, as he could talk about "Poetry, Painting \& Music, the three Powers in Man of conversing with Paradise, which the flood did not Sweep away." Every work of art is an open window into eternity. God appears to man in art. Artistic inspiration is the same as the union with God. There is an unio artistica, a sister to the unio mystica. To conclude: Blake accepts that reason cannot grasp the divine vision and understand it. That is why he always talks of the vision as appearing in stronger and better lineaments, and a stronger and better light than nature can produce or mortal and perishing organs can apprehend. But art can grasp it. The central conception of mysticism, the undescribable unio mystica, is present in Blake. He is a mystic. The only difference between Blake and the classical mystics is in terminology. When they say "God" Blake very often says "Art".

Blake, at least, thought that his "art" meant the same as their "God"but would the mystics agree? Is their $\mathrm{x}$ the same as Blake's $\mathrm{x}$, really? This we cannot know. But we must accept that it is the same, or else make the word "mysticism" completely meaningless. For we do not know if the $\mathrm{x}$ of Plotinus is the same as the $\mathrm{x}$ of Theresa. They seem to be, but since we cannot describe in precise words the nature of the unio mystica, argument is useless. They resemble each other, consequently we put them into the same group, that of the mystics. Blake resembles them too, and must, on the same ground, be accepted as one of the group. ${ }^{2}$ For, if we are not quite certain as to the degree of resemblance, neither can we name any characteristic in Blake which would be inconsistent with the lives and works of the great mystics. We must choose: either accept Blake as a mystic, or insist that the word "mystic" be excluded from the language. I prefer the first alternative.

\footnotetext{
1 "Last Judgment", Note-book, BM, pp. 80 f. (Complete Writings p. 609).

${ }^{2}$ J. G. Davies, who in The Theology of William Blake, 1948, and ed. 1966, tries to make a strongly heterodox Christian an almost completely orthodox one, recognizes Blake's resemblance to the mystics in chap. IV, "Blake and Mysticism", but concludes less convincingly, quoting Miss Underhill, that Blake became more and more "passionately and dogmatically Christian" (2nd ed. p. 8I).
} 